\title{
Curiosa in fine needle aspiration biopsy of the thyroid gland
}

\author{
Stanisław Sporny \\ From 4th Congress of the Polish Thyroid Association 2013 \\ Lodz, Poland. 11-13 April 2013
}

The great importance of cytological examination in diagnostic procedures of thyroid gland pathological lesions is widely known. Unfortunately, cytology as a diagnostic method presents many limitations due to possible presence of elements abnormal for thyroid gland physiology and histology. Especially difficult in cytological diagnosis appear: among non-neoplastic lesions - dyshormonogenetic and amyloid goiter and Riedel disease and among neoplastic lesions - rare microscopic variants of tumours, neoplasms arising from ectopic tissues and nonepithelial tumours.

Published: 5 April 2013

Submit your next manuscript to BioMed Central and take full advantage of:

- Convenient online submission

- Thorough peer review

- No space constraints or color figure charges

- Immediate publication on acceptance

- Inclusion in PubMed, CAS, Scopus and Google Scholar

- Research which is freely available for redistribution 